Journal of Indonesian Applied Economics, Vol.6 No.1, 2017: 71-83

\title{
TRUMP'S ELECTED SHOCK EFFECT ON INDONESIAN STOCK MARKET
}

\author{
Vietha Devia Sagita* \\ Department of Economics \\ Faculty of Economics and Business, University of Brawijaya
}

\begin{abstract}
It is inevitable that the presidential election in the United States can cause stock market fluctuations both in the United States alone and in other countries, for example Indonesia. Using a regression method and chow test, this study aims to investigate the effects before and after the election of Donald Trump as a president of the United States on November 8, 2016 on Indonesian stock market. Using the data series of the value of DJIA and ICI, this study analyzes the emergence of shock due to the change of the president in United States on the share prices at the stock market in Indonesia. Based on the chow test result, the election of Donald Trump can provide a shock effect on ICI and DJIA because the value of $6.917956 \mathrm{~F}$ count is larger than the value of 3,93 F table. DJIA has positive influence on the value of ICI shares and is significantly below 5\% at 1855.782 due to the election of Donald Trump. Meanwhile, before the election of Donald Trump, DJIA had a negative influence on the ICI for - 1407.59. Based on the result, it is concluded that the election of Donald Trump brings a good impact on the growth of the Indonesian stock market.
\end{abstract}

Keywords: DJIA, ICI, Stock Market, American Presidential Election.

JEL Classification: G10, G15

\section{INTRODUCTION}

The capital market is a today's economic instrument which has developed very rapidly. The stock market is the progress indicator of a country's economy and to support the economy the concerned country (Ang, 1997). Capital market has an important role for the economy of a country because the stock market runs two functions: first as a means of funding for business or as a means for companies to obtain funds from investors (Husnan, 2004). The funds obtained from the capital market can be used for business development, expansion, capital increase labor and others. Besides, the capital market serves as a means for the community to invest in financial instruments such as stocks, bonds, mutual funds, and

*Corresponding e-mail: vietha.devia@ub.ac.id 
others. Thus, people can put funds they have in accordance with the characteristics of their respective advantages and the risks of these financial instruments.

Investing activities either directly or indirectly are with the hope that in the meantime the owners of capital will get some benefit from the results of these investments. In the capital market, the investors can choose an object with diverse investment rate of return and the level of risk, while publishers (issuers or issuers) can raise funds to support the long-term business continuity through market capital.

One of the activities of investment that can be selected by the investor is to invest in the capital market. In Indonesia, investors who are interested in investing in the capital market can invest in the Indonesia Stock Exchange (BEI). Indonesia Stock Exchange itself is an amalgamation of Jakarta Stock Exchange and Surabaya Stock Exchange on December 1, 2007. This incorporation is done for the sake of operational efficiency and effectiveness and transaction.

To provide more complete information to investors about the development of the exchange, BEI disseminates stock price data through print and electronic media. One indicator of stock price movement is the stock price index. Currently, BEI has seven kinds of stock index (www.idx.co.id):

1. Indonesia Composite Index (ICI)

All of the Listed Company is used as a component Index calculation.

2. Sectoral Index

All listed companies are included in the each sector. Today, there are 10 sectors in BEI namely Agriculture, Mining, Basic Industry, Arts Industrial, Consumer Products, Real Estate, Infrastructure, Finance, Trade and Services, and Manufacturing.

3. LQ45 Index

The index consists of 45 stocks of selected listed company based on the considerations of liquidity and market capitalization, with the criteria that have been determined. Review and replacement stock are performed every 6 months.

4. Jakarta Islamic Index (JII)

The index uses 30 stocks selected from sharia qualified shares (Sharia Securities List published by Bapepam-LK) by considering market capitalization and liquidity.

5. Kompas 100 Index 
The index consists of 100 stocks of chosen listed companies based on considerations of liquidity and market capitalization, with the criteria that have been determined. Review and replacement stock are performed every 6 months.

6. BUSINESS-27 Index

The cooperation between the Indonesian Stock Exchange with the Business Daily Indonesia launched a stock index named Index BUSINESS-27. The index consists of 27 stocks of listed companies which were selected based on criteria fundamental, technical or accountability, transaction liquidity and corporate governance.

7. PEFINDO 25 Index

The cooperation between the Indonesian Stock Exchange with PEFINDO rating agencies launched stock index named PEFIND025 index. This index is intended to provide additional information for investors, especially for stocks of small and medium-sized issuers (Small Medium Enterprises / SME). This index consists of 25 stocks of selected listed companies taking into account such criteria as: Total Assets, the return on capital (Return on Equity / ROE) and public accountant opinions. In addition to the above criteria, liquidity factor and the number of shares owned by the public are taken into consideration.

8. SRI-KEHATI Index

This index is formed on cooperation between the Indonesian Stock Exchange with the Indonesian Biodiversity Foundation (KEHATI). SRI stands for Sustainable Responsible Investment. This index is expected to provide additional information to investors who want to invest in issuers that have performed in encouraging sustainable business which has awareness of the environment and executes governance good company. This index consists of 25 shares of the selected listed companies taking into account the criteria such as: Total Assets, Price Earnings Ratio (PER) and the Free Float.

9. Main Board Index

The listed company's shares are included in the main board.

10. Development Board Index

The listed company's shares are included in the development board.

11. Individual Index

Share price index of each of the listed companies. 
One index that is often overlooked by investors when investing in the Indonesia Stock Exchange is the Composite Stock Price Index. This index shows all shares listed on the Stock Exchange Indonesia (http://id.wikipedia.org/wiki/ICI). Therefore, through the movement of the stock price index, an investor can see market conditions whether it is exciting or lethargic. Different market conditions require different strategies for investors in investing.

Many factors can influence the stock index, among others are changes in central bank interest rates, global economic conditions, the level of world energy prices, and political stability of a country. In addition to these factors, the behavior of investors themselves will also affect on the movement of stock index.

Today the industry in Indonesia is experiencing a period of growth (www.bappenas.go.id). These are the companies which are active in export and import activities. One of the factors that launched export and import activities is the currency as a means of transaction. One currency that is commonly used in trade International is the US dollar. For companies engaging in the active export and import activities, the stability of the exchange rate dollar against the rupiah is important. Because when the value of the rupiah depreciates with the US dollar, this will cause increasing prices of the imported goods. If the majority of raw materials companies use is imported materials, it will automatically lead to the increase of production costs. The increase in production costs will certainly reduce the level of corporate profits. The reducing level of corporate profits will certainly influence buying interest of investors in the shares of the company concerned. In general, it will push down the stock price index in the country.

Indonesia's own economy is now increasingly integrated in the global economy. Indonesia's economy is open on the side balance of payments ranging from trade, capital inflow or outflow, and the activities of the government through the withdrawal and payment of foreign debt (www.antara.com). United States is the largest non-oil export country destination of Indonesia. Changes in economic conditions in the country will certainly influence, either directly or indirectly, to Indonesia. If the economies of both countries are experiencing recession, this would cause the value of non-oil exports Indonesia to these countries go down, because consumers in the country which is in a state of economic recession will certainly reduce the level of spending. 
In addition to an export destination country of Indonesia, United States is the largest economy in the world (www.kompas.com). It is based on that in 2015 gross domestic product of the country represent $24.42 \%$ of total worldwide gross domestic product (www.imf.org). Thus, it is obvious that changes in economic circumstances of the country are able to influence the Indonesian economy, either through exports-imports of goods and services, the flow of funds from the state investor, or changes in the level of business risk in the country. One variable economy that can be used to measure economic performance of a country is the stock index in the country. It is possible because automatic investors will be attracted to invest their funds in the stock market of the concerned country when the country has a bright economic outlook. This will encourage the times bullish that will encourage the movement of stock indices. On the other hand, when the perceived atmosphere of gloomy economy is reflected, the stock index will go down.

In The United States, the index that can be used as a proxy is The Dow Jones. The Dow Jones is the oldest stock market index in the United States and is a representation of the performance of the industry which is the most important sector in the United States (www.nyse.com). Companies listed in The Dow Jones generally multinational companies. Their operations are spread across the globe. Companies such as Coca-Cola, ExxonMobil, Citigroup, Procter \& Gamble are such example companies listed on the Dow Jones and operate in Indonesia (www.kompas.com). These companies generally operate directly in Indonesia. If The Dow Jones moves rising, it indicates that the performance of the US economy in general is in a good position. With good economic conditions, Indonesia will move the economy through export activities and capital inflows both direct investment and through market capital. Inflows through the capital market will certainly have an influence on changes in ICI.

A study conducted by Achsani (2000) on how the stock responds to shocks from other exchanges, in case of shock in the United States, the result showed that the regional exchanges did not respond very much. Only in Singapore, Hong Kong, Japan and Taiwan and New Zealand, the respond was shown immediately, and the response was not large enough. Conversely, if the shock happens in Singapore, Australia or Hong Kong, the shock will quickly be transmitted to almost all stock markets in Asia Pacific, including the Indonesia. 
After Donald Trump officially becomes president of the United States (US), the negative response is given the capital market. In fact, the stock Dow Jones and Asian stock prices fell sharply, as investors panicked over the uncertainty about trade, immigration and geopolitical tensions in the hands of Trump fore. At one point, the Dow Jones fell more than 4 percent and Japan's main index lower than 6.1 percent, the biggest decline this year. During the campaign, Trump promised to severely restrict immigration to the United States and will build a wall along the southern border of the United States and force Mexico to pay for it. However, the lack of a clear policy details have made many investors around the world anxious about the future direction of the US economy. The stock price began to fall soon after the first time Trump leading the vote count. At the time Trump led 276 electoral votes, passing the important 270 mark; financial markets seemed restless and worried. However, most market watchers predict that anxiety or chaos in this market will only occur briefly because Trump policy will be known, and are sure to be more acceptable to the market rather than what he says during the campaign. Investors may already imagine the worst case scenario. Any shocks or turbulence in the markets caused by the election results will be short lived and economic fundamentals will play a crucial role in the performance of financial markets. The stock market in free fall was recorded on $9^{\text {th }}$ November 2016 on Wall Street, Dow Jones futures down 3.2 percent or 489 points at $17,803.00$. S \& P futures fell 3.1 percent to 2,070.10.

Donald John Trump victory over Hillary Rodham Clinton in the presidential election would benefit the United States projected capital market, stock price index (CSPI) and Indonesia. Negative reactions on the election of Republican Donald Trump to become the 45th US president replacing Barack Hussein Obama are expected to be temporary. Indonesia expects no strong capital inflow as when Britain was out of the EU or Brexit. Although the composite stock price index (JCI) dropped 1.03\% closed at 56.36 points to 5414.32 with $17.88 \%$ gains year-to-date, JCI reacted negatively for the first time in 16 years and five times the US elections. Foreign investors posted a net selling worth Rp56 billion. Foreign market players recorded have released a portfolio with a notch $\operatorname{Rp} 3,27$ trillion net sell since October 2016. Net sell makes the net buy achievements since the beginning of the thinning becoming $\mathrm{Rp} 31,18$ trillion. The negative sentiment was estimated to be only temporary due to increased uncertainty. However, the global and 
domestic markets are projected to recover in line with the improvement of the national economy. Trump programs to evaluate trade relations with China and Mexico are projected to have a positive impact for Indonesia. Business and US investment in China are expected to turn to Indonesia, including the funding of infrastructure projects funded by the US China. Trump made his election chances of the Federal Reserve to raise interest rates. It is estimated that Fed was not going to hoist the interest rate of the Fed Funds Rate (FFR) in December 2016. The results of the US presidential election would add energy to the window dressing that occurred at the end of the year on the trading floor. Index trends are still on track with projections bullish end of the year at the level of 5500-5600.

Some of the current conditions within and outside the country as outlined above underlie the authors to conduct research on the changing relationship of stock prices in the Indonesian stock market, known as Indonesia Composite Index (ICI) with the stock price changes in US markets, known as Dow Index Jones Industrial Average (DJIA) as a result of the election of Donald Trump as the 45th president of American.

\section{LITERATURE REVIEW}

\section{Dow Jones Industrial Average (DJIA)}

Dow Jones Industrial Average (DJIA) is one of the indices used as benchmarks in the US economy, especially the stock market. Two others, namely Nasdaq Composite index and Standard \& Poor's 500 are also commonly used as a measure of the performance of the capital markets in the United States. However DJIA is considered to be the best measurement of the performance of capital markets. The Dow Jones Industrial Average (DJIA) is a price-weighted average of 30 significant stocks traded on the New York Stock Exchange (NYSE) and the NASDAQ (Anonymous, 2017).

DJIA was first used in 1882, by calculating the average of nine-stock transportation index includes shipping, railway, and telecommunication stocks. DJIA was used as the primary gauge of the performance of stock markets because it is a "blue-chip" index, which means it is comprised of the stocks of relatively few large and prominent companies (A CME Group Company, 2012). Furthermore according to Kosakowski (2017), as long as it contains the stocks of companies that reflect the major industrial areas of the U.S. economy during any given period, this 30 -stock index will likely be the gold standard of financial 
indicators. Therefore, the movement of the stock represents the movement of other stocks which are on the second and the third liners.

\section{Indonesia Composite Index (ICI)}

Indonesia Composite Index is a measurement of the performance of the Indonesian stock market. If the DJIA is the oldest index in the US, the ICI is the oldest index in Indonesia. There are several other indexes, namely the sectoral indices, LQ45, Jakarta Islamic Index (JII), Compass 100, Bisnis 27, PEFINDO 25, and SRI - KEHATI. However, ICI is considered as the most excellent stock market measurement. That is because ICI contains all shares which are listed on the Indonesia Stock Exchange.

ICI was used first by Indonesian Stock Exchange (BEI) in 1983. According to (www.idx.co.id), in order to describe the state of stock market, Indonesia Stock Exchange is authorized to issue or re-enter one or more of listed company of the ICI calculation. If the amount of listed company's shares held by the public (free float) is relatively small while the market capitalization is quite large, the change in the stock price has the potential to effect of the fairness ICI movement.

\section{Previous Empirical Studies}

Muharam and Nurafni (2008) conducted the research about relationship between the DJIA and ICI. The research analyzed how the effect of exchange rates (IDR) and DJIA against ICI. The results from the study show that the exchange rate (IDR) negatively affects the ICI, while the DJIA has positive effect on JCI.

Another study conducted by Ernayani and Mursalin (2015) analyzed the relationship of dollar exchange rate (USD), Dow Jones Index and Interest Rate SBI Against ICI (January 2005 - January 2015). The results showed that the dollar exchange rate (USD) has no effect on ICI. As for the Dow Jones, it has positive effect on ICI, while SBI has negative effect on ICI.

Li et al (2017) studied about market impact and structure dynamics of the Chinese stock market based on partial correlation analysis. The results showed that the native market index has a great impact on the market correlations for both the Shanghai and Shenzhen stock markets. Besides some external stock indices of the United States, European and Asian stock markets show a slight influence on the Chinese market. 


\section{RESEARCH METHODS}

The data used for the analysis in this study are the daily data of the native stock markets and the external stock markets from $1^{\text {st }}$ September 2016 to $24^{\text {th }}$ January 2017. Indonesia Composite Index (ICI) is analyzed for the internal market, while Dow Jones Industrial Average (DJIA) is analyzed as an external market.

Data analysis method which is used in this research is chow test breakpoint. The purpose of using this method is to see the effect to DJIA before and after Trump election as President of the United States and then the effect of DJIA to ICI. The model is used as follows:

$$
y t=a+b x_{t}+e
$$

Then the model is divided into two as follows:

$$
\begin{aligned}
& y t=a_{1}+b_{1} x_{t}+e \\
& y t=a_{2}+b_{2} x_{t}+e
\end{aligned}
$$

Where:

$\mathrm{y}=\mathrm{JCI}$

$\mathrm{x}=$ DJIA

With the following hypotheses:

H0: $\mathrm{a}_{1}=\mathrm{a}_{2}$ and $\mathrm{b}_{1}=\mathrm{b}_{2}$

$\mathrm{H}_{1}: \neq \mathrm{a}_{1} \mathrm{a}_{2}$ and $\mathrm{b}_{1} \neq \mathrm{b}_{2}$

\section{RESULTS AND DISCUSSION}

The results of data analysis showed that the $\mathrm{F}$ table is equal to 3.93 and $\mathrm{F}$ count is 6.917956, so it can be seen that the F count is > F table. Thus, HO is rejected and H1 is accepted. The conclusion that can be drawn is that Trump's election as President of the United States affects on the DJIA. After Trump was elected as the president of the United States, the DJIA has increased significantly. The day before Trump elected, the DJIA stood at 18332.74 .

Trump was elected as President on November 9, 2016. The day after Trump elected, DJIA increased by 475.14 points to 18.807. 13 days after Trump was elected, on 22 
November 2016 DJIA went through 19,000, becoming 19023.87. Even Wall Street in the United States (US) set a new record in trading on Wednesday (25/01/2017). For the first time, Dow Jones was up to 20,000 (sport.detik.com, 2017).

Figure 1 DJIA after Trump's Elected

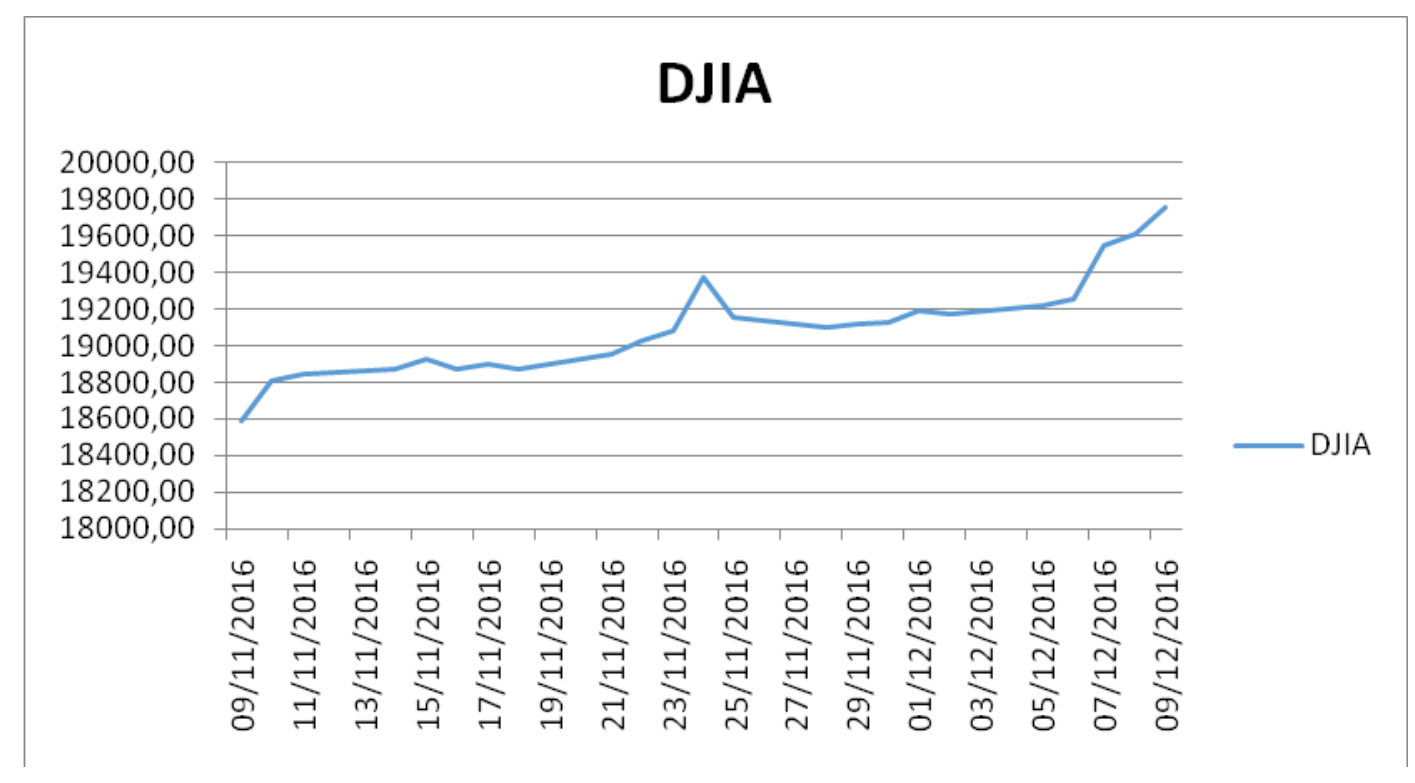

The influence of DJIA on JCI before Trump was elected as the president of the United States is shown from regression analysis results. Based on the results of regression, probability value is 0.0304 or it can be said that probability value is $<0.05$. With the $5 \%$ significance, it can be concluded that DJIA affects on the ICI. Moreover, the data analysis showed that before Trump was elected, DJIA had a negative influence on the ICI for 1407.59.

Before the Trump's election, the stock market in Indonesia had a positive sentiment that Hillary Clinton would win the President's election. Even one day before Trump was elected, ICI achieved the highest intraday point. According to Pramisti (2017), optimism of Hillary Clinton's victory made passionate stock markets, including Indonesia. Moreover according to Astria and Nugroho (2016), ICI is in line with the strengthening exchanges of other southeast regions. The US presidential election on November 8 is seen to become the main catalyst of global exchanges. 
The movements of JCI showed a slight change and had decreased due to the bad issue about Hillary Clinton. However, ahead to 9 November 2016, ICI rose sharply. Even the rise of ICI reached the highest level. Issues of Hillary Clinton during the FBI investigation made the Hillary's popularity declining. Nonetheless, after Hillary's mail was declared that there was no problem and the investigation was closed, the positive market responded immediately. When the surveys sticked up Hillary to become the winner of the presidential election, ICI also carried positive euphoria with large increases for 3 days ahead of the presidential election (Anonoymous: 2016).

On the other hand, DJIA showed contrast conditions to ICI before the US presidential elections. The investors had a negative sentiment if Trump won the elected. As a result, the DJIA had decreased dramatically. Before Trump declared his victory, the futures on Dow Jones tumbled by 800 points (tirto.id: 2016).

The relationship between DJIA and JCI after Trump was elected showed a different result. DJIA has positive influence on the ICI value due to the election of Donald Trump with the value of significantly below $5 \%$ at 1855,782 . It means when the DJIA has increased, it will be followed by the increase of ICI. Conversely, if the DJIA decreases, the ICI also decreases.

The day after Trump was elected as the president of the US, the DJIA rose. Wall Street soared. The Dow Jones rose 1.4 percent in trading Wednesday (09/11/2016) (Marta: 2017). The rise in the DJIA was not immediately followed by an increase in ICI. After Trump was elected, the stock market had decreased in some countries, including Indonesia, Japan, China and Singapore. However, the decline occurred only a moment. The decline in ICI only occurred after the declaration of trump's winners, but on the next day, ICI moved up to the green zone. On $10^{\text {th }}$ November 2016, the ICI in Indonesia Stock Exchange (BEI) consistently moved in the green zone since the morning session and closed up 35.99 points $(0.66 \%)$ (Anonymous 2016). 


\section{CONCLUSION}

The conclusions that can be drawn is that Trump's election as the president of the United States affects the DJIA. After Trump was elected as the president of the United States, the DJIA has increased significantly. Related to the effect of DJIA to ICI, with the 5\% significance, the result showed that DJIA affects on the ICI. However, the data analysis showed that before Trump was elected, DJIA had a negative influence on the ICI for 1407.59. The relationship between DJIA and JCI after Trump was elected showed a different result in which DJIA has positive influence on the ICI value, with the value of significantly below $5 \%$ at 1855,782 .

\section{REFERENCES}

Achsani, N. A. (2000). Mencermati Kejatuhan Indeks Dow Jones: Akankah Indeks BEJ Ikut Terseret. University of Potsdam. Potsdam.

A CME GROUP COMPANY. "Five Questions About The Dow, That You Always Wanted to Ask".https://www.djindexes.com/mdsidx/downloads/brochure_info/Five_Questions _Brochure.pdf, 2012, accessed Februari 2, 2017.

_. 2017." Market Perspective, Wealth Management Newsletter Nov 2016: US Elected Effect".

http://www.commbank.co.id/lib_ui/repository/doc/MarketPerspectiveNovember20 16.pdf, 2017, accessed Februari 8, 2017.

_. Stock Market Rebound: Negative Sentiment As a Result of President Election Became Calm". https://beimediahariini.wordpress.com/2016/11/11/pasar-saham-rebound/, 2016, accessed Februari 5, 2017.

Ang, R. (1997). Buku Pintar Pasar Modal Indonesia (The Intelligent Guide to Indonesian Capital Market). Jakarta: Mediasoft Indonesia.

Astria, Riendy \& Nugroho, Aprianto Cahyo. Stocks Exchange, November $9^{\text {th }}$ index closed down sharply by 1.03.http://market.bisnis.com/read/20161109/7/600534/bursasaham-9-november-ihsg-melonjak-di-hari-ketiga-cermati-laju-hari-ini, 2016, accessed Februari 8, 2017.

Husnan, S. (2004). Dasar-Dasar Teori Portofolio dan Analisis Investasi. Penerbit UPP-AMP YKPN. 
Kosakowski, Paul." Why The Dow Matters".http://www.investopedia.com/articles/stocks/08/dow-history.asp, 2017, accessed Februari 2, 2017.

Li, X., Qiu, T., Chen, G., Zhong, L. X., and Wu, X. R. (2017). Market impact and structure dynamics of the Chinese stock market based on partial correlation analysis. Physica A: Statistical Mechanics and its Applications, 471, 106-113.

Martha. “Trump's Effect Testing Indonesian Economic". http://bisniskeuangan.kompas.com/read/2016/11/12/060120726/efek.trump.men guji.perekonomian.indonesia, 2017, accessed Februari 5, 2017.

Muharam, Harjum dan Nurafni, Zuraedah. "The Effect Analysis of Exchange Rate and the Dow Jones Industrial Average to Indonesia Composite Index in Jakarta Stock Exchange". http://eprints.undip.ac.id/38909/1/scan_030001.pdf, 2008, accessed Februari 5, 2017.

Pramisti, N Qomariyah. "Donald Trump and Stock Market Issues in 2016". http://tirto.id/donald trump-dan-gonjang-ganjing-pasar-saham-2016-cdGU, 2017, accessed Februari 5, 2017.

sport.detik.com: Print Records."Wall Street, the Dow Jones Emerging 20,000". http://detak.online/infofin.php?file=bursa-dan-valas/d-3405751/wall-street-cetakrekor-dow-jones-tembus-20000, 2017, accessed February 8, 2017.

Wagner, Harvey M. "Linear Program-ming Techniques for Regression Analysis," Journal of the American Statistical Associa-tion, LIV (1959), 206-12. 